\title{
Evaluating Neighborhoods Developed Open Spaces in Khartoum-Sudan
}

\author{
Zuhal Eltayeb Awad \\ Department of Architecture and Physical Planning, Institute of Building and Road Research, University of Khartoum, Sudan
}

Copyright $\subseteq 2018$ by authors, all rights reserved. Authors agree that this article remains permanently open access under the terms of the Creative Commons Attribution License 4.0 International License

\begin{abstract}
The research reported in this paper, evaluated development of open areas in neighborhoods. The research was performed in the new neighborhoods in Khartoum town (Al Riyadh (1972), Nasr Extension (1972) and Al Mujahedeen (1988), compared to older neighborhoods (Khartoum -2 (1950), Al Diyum (1953), and Alamarat (1958)). The research aimed to study open spaces in these neighborhoods. Compared with characteristics of the selected neighborhoods, classified developed open spaces and evaluated the performance of each typology. The research promoted measurable development indicators such as availability, accessibility, safety and management. Then apply these indicators to analyze developed open spaces. The results confirmed a lack of a comprehensive development programs. The developed open spaces are 35 with total area of $154,050 \mathrm{~m}^{2}$ which represent only $27.6 \%$ of the total number of open spaces. The research found that old neighborhoods have higher index of sufficiency value than new neighborhoods e.g. Khartoum (2) (8.9) compared to Al-Mujahdeen (5.2). Also, first class residential areas have higher index value than third class areas e.g. Khartoum -2 (8.9) compared to Al-Diyum (7.7). The successful types of developed open spaces of the surveyed neighborhoods are Recreational open spaces and Community centers. Most of them are managed by community groups (public participation).
\end{abstract}

Keywords Neighborhoods, Open Spaces, Measurable Indicators, Development

\section{Introduction}

Urban open spaces promote and enrich the social, economic, environmental and cultural wellbeing of communities, commonly called the "four wellbeing's [1]. Some urban open spaces have iconic value - being significant features in their settings and reflect the local culture or history e.g. Central Park in New York Champs-Elysées in Paris or El Tehrer Square in Cairo. In addition to that, they raise real estate values e.g. Central Park and Bryant Park -located in Manhattan, New York City are two examples of urban open space that add economic value to their surroundings [2]. Scholars added a political dimension to the important role of urban open spaces in the $21^{\text {st }}$ century and described parks as "places where democracy is worked out literally on the ground, and therefore the way such spaces are designed, managed and used demonstrates the realities of political rhetoric "[3]. Public parks conceived as places where strangers can meet, so that there is a great chance of privacy [3]. At the micro level green spaces are important components of the neighborhoods which increase the quality of the urban environment. They offer common grounds for social contact and interaction between neighbors [4]. Open spaces have broad and diverse benefits for neighborhoods residents especially those who are least freely mobile, because of lack of private transport, age or illness like old people [5]. The social impact of access to green spaces in neighborhoods is improvement of social inclusion and community cohesion [6]. Using green space is an expanded indicator for sustainable cities and improves both the health and the well-being of urban residents [7]. There is a strong link between health and the cultural ecosystem services [8]. The social determinants of health and the benefits gained from urban green spaces are listed in table 1. At neighborhood and built environment level they promote sense of place and community satisfaction, reduce crime and incivilities and provide access to healthy food.

The growing amount of people living in urban areas -approaching two thirds of the global population -creates many challenges concerning health hazards and risks. Research on lifestyle impact of green space and quality of life revealed that physical exercise in green spaces is generally positively associated with promoting well-being and recovery from stress [9], also landscape patterns characteristics influence the mental health of nearby residents [10].Many scholars studied the environmental and ecological impact of green space such as: natural reservation, protection of habitat, preservation of bio-diversity, improvement of urban climate, reduction of 
air pollution and noise and clearance of contamination[11]. Therefore, the broad and diverse benefits of green networks can be summarized into two main categories, Primary Benefits and Secondary Benefits. Primary Benefits includes: Accessibility, sustainability, high quality, positive image, promotion of economic development and, promotion of social inclusion. Secondary Benefits includes: ecological, environmental and educational benefits [12].

Table 1. Connections between social determinants of health and benefits linked to cultural ecosystem services provided by urban green spaces. Source: [8]

\begin{tabular}{|l|l|}
\hline $\begin{array}{l}\text { Social Determinant of } \\
\text { Health }\end{array}$ & $\begin{array}{l}\text { Benefits linked to Cultural } \\
\text { Ecosystem Services }\end{array}$ \\
\hline \multirow{4}{*}{ Health and health care } & Physical Well-Being \\
\cline { 2 - 2 } $\begin{array}{l}\text { Neighborhood and built } \\
\text { environment }\end{array}$ & Psychological Well-Being \\
\cline { 2 - 2 } & Sense of Place \\
\cline { 2 - 2 } & Community Satisfaction \\
\hline \multirow{2}{*}{$\begin{array}{l}\text { Social and community } \\
\text { context }\end{array}$} & Access to Healthy Food \\
\hline \multirow{2}{*}{ Education } & Social Cohesion \\
\cline { 2 - 2 } & Social Capital \\
\hline \multirow{2}{*}{ Economic Stability } & Academic Performance \\
\cline { 2 - 2 } & Cognitive Functioning \\
\hline
\end{tabular}

Not understanding or acknowledging the above-mentioned benefits of green spaces in urban areas by professionals and active members in industry, have led to the deteriorating condition of urban green spaces in Africa .The reasons of that deterioration are: high rates of urban sprawl and informal settlements e.g. reduction in green vegetation from $21 \%$ to $12.9 \%$ in Abuja [13] or reduction of forests area, although the existence of natural green space such as a forest may be seen as a substitute for urban green spaces [14]. Regarding the Sudanese context, most of open spaces in Khartoum town are neglected and left undeveloped-brownfields- for a long time. A main problem is that neglected open spaces seem to attract anti-urban behavior such as collecting rubbish or unwanted building materials. They produce health hazards especially in times of rains as being a suitable habitat for insects in particular mosquitos. Moreover, the contemporary urban growth of neighborhoods in Khartoum town and the growing demand for residential areas have a considerable impact on change of open space use. The public authority transforms undeveloped open spaces into other uses e.g. social services: mosques, schools or shopping centers, or even sold them as residential land. This transformation had negative consequences on the quality of neighborhoods and the social life. Some active community organizations and community members start developing open spaces so that public authority could not transform them into other uses. The main objective of this research is to recognize and evaluate the developed open spaces in the selected neighborhoods.

\section{Open Space Typology}

Open spaces can be classified according to functions or characteristics. There is a simple typology that divided urban landscape types into four main categories [15]:

- Urban common: includes brownfields, vacant land, back land and informal open spaces.

- Encapsulated country- side: includes natural features-river valleys and woodlands.

- Working landscape: includes farms, forestry and allotments for food production

- Formal landscape: includes parks, gardens and institutional grounds for recreation.

Another detailed typology focusing on land uses to serve planning purposes [16], where open spaces are divided into:

- Green Spaces -parks and gardens: includes urban and country parks, and formal gardens - formal landscape

- Amenity green spaces: including: housing green spaces, domestic gardens, village greens and other incidental space- informal recreation spaces in residential areas.

- Allotments, community gardens and urban farms.

- Natural and semi-natural green space: includes woodland and scrub grassland, heath or moor, wet lands, open and running water and bare rock habitat

- Green corridors: includes river and canal banks, road and rail corridors, cycling routes and pedestrian paths within towns and cities and rights of way and permissive paths.

A recent study presented eight categories of urban green spaces [17]:

- building greens,

- private, commercial, industrial, institutional urban green space and urban green space connected to grey infrastructure

- riverbank green,

- parks and recreation,

- allotments and community gardens,

- agricultural land,

- natural, semi-natural and feral areas

- blue spaces.

From the above-mentioned typologies, it is clear that scholars classified neighborhood open spaces in different ways: it was classified with formal landscape [15], and with the informal recreation spaces- amenity green [16], and finally it was placed in the park and recreation typology and outlined many benefits of them such as: during WW II, neighborhood green was changed into tenant gardens producing food [17]. 
However, neighborhood open spaces have many uses and perform multiple functions such as: recreation, cycling routes and pedestrian paths and sport fields. It must be seen as "multi-functional area for social interaction, economic exchange and cultural expression among a wide diversity of people and should be designed and managed to ensure human development, building peaceful and democratic societies and promoting cultural diversity" [18]. Therefore, neighborhood open space could be classified in the main formal landscape section with different typologies according to its purpose.

\section{Sustainable Development of Open Spaces}

Sustainable development is seen as a process that links environmental protection with economic, social and cultural sound development. Urban development is a major concern in sustainable issues so that cities and human settlements must be inclusive, safe, resilient and sustainable [19]. Development of open spaces has to be within the umbrella of the four pillars of sustainability: cultural vibrancy, economic prosperity, environmental responsibility and social justice [20]. Some researchers tried to connect neighborhoods sustainability and open space development, by developing a three-dimensional matrix corelating different typologies of open spaces with sustainability goals and objectives, and sustainability parameters [21].

The Sustainable Development Goals (SDGS) are a collection of 17 global goals set by the United Nations General Assembly in 2015. They were set to guide development, end poverty, protect the planet and ensure that all people enjoy peace and prosperity [19]. Goal 11 clearly stated that green and public space development is a major concern in urban sustainability: "by 2030, provide universal access to safe, inclusive and accessible, green and public spaces, particularly for women and children, older persons and persons with disabilities" [19]. The three mentioned indicators in Goal 11 are: safety, inclusion and accessibility. How to measure open space development is a debatable issue and monitoring the progress and application of these goals is not practical [22]. Moreover, World Health Organization identified the most important aspects of development of green environment as: availability, accessibility, quality and security [7].

Therefore, the international indicators to control provision of open space are:

\subsection{Availability}

Provision of open spaces in urban areas can be monitored by goal $/$ target as - $45 \%$ of land in urban areas with a minimum density of 150 inhabitants per hectare should be allocated to streets and public space [18]. 15\% of land should be allocated to open spaces, green spaces and public facilities [18]. The index of sufficiency of open spaces is the fraction of the square meters of open space by the number of the neighborhood inhabitants. The recommended square meters of green space per capitaindex of sufficiency- globally is a minimum of $9 \mathrm{~m}^{2}$ per person [7], but some European cities applied different monitoring values e.g., Berlin: $6 \mathrm{~m}^{2}$ per person, Leipzing: $10 \mathrm{~m}^{2}$ per person. The British standard for the natural green aimed to provide 2 hectors of natural green space for urban inhabitants with accessibility of $300 \mathrm{~m}$, while the German standard reduced the amount to 0.5 ha with accessibility of $500 \mathrm{~m} \mathrm{[17].}$

\subsection{Accessibility}

Accessibility means the right to approach, to enter or use particular open space-without presence of any physical constrain e.g. long distance, roads, railways locked gates or social and cultural constraints e.g. fear of crime or other concerns over safety [12]. In some situations, accessibility is connected with safety. Access to open spaces within a 15 -minute walk is regarded as one of the core health indicators of sustainable cities [23]. There are a number of "distance/time" criteria for measuring accessibility for parks and gardens -the British standard proposed the following hierarchy of accessibility [15]:

- $\quad 300 \mathrm{~m}$ to the nearest 2 ha green space.

- $2 \mathrm{~km}$ to the nearest 20 ha green space.

- $5 \mathrm{~km}$ to the nearest 100 ha green space.

- $10 \mathrm{~km}$ to the nearest 500 ha green space.

Accessibility is an important planning indicator. Improving technologies enable planners and researchers to use geographical information system (GIS) to analyze availability and accessibility of green spaces within urban areas. They used (GIS) to outline some valuable green spaces in terms of ecological, recreational and aesthetical impact [24] and [25]. Geographical Information System (GIS) helped to create a model for management of existing green spaces and distribution and planning of new green spaces in neighborhoods [26]. Moreover, they used GIS to quantify and measure the access of green space by different ethnic and religious groups [27].

\subsection{Security}

The safety of women, the elderly and children is an important key indicator for the development of open space. The total recorded crime rates in the world (1980-2000) increased by about $30 \%$ and it is estimated that about $15 \%$ of those crimes have took place in a public space [28]. Security can be guaranteed through provision of lighting and fencing, although fencing enhances the social inclusion dimension.

\section{The Sudanese Context}

Open spaces in Khartoum have been classified into four 
main classes based on parameters of number of population served and zone of service, see table 2 below.

Table 2. Classification of open spaces in Khartoum (source: [29]).

\begin{tabular}{|l|l|l|}
\hline Open space & No. of population & Service zone $\left(\mathrm{m}^{2}\right)$ \\
\hline Neighbourhood court & $500-5000$ & $300-500$ \\
\hline Residential garden & $10,000-20,000$ & $2,000-5,000$ \\
\hline Communal garden & $20,000-50,000$ & $2,000-5,000$ \\
\hline City park & $100,000-150,000$ & Bigger than that \\
\hline
\end{tabular}

The Sudanese standards for open spaces aimed to provide 4 open spaces in a small neighborhood -2000 people, each one is 0.16 hector in area [30]. The recommended square meters of green space per capita locally is $1.5-0.40 \mathrm{~m}^{2}$ for open space in small neighborhoods and $1.7-0.80 \mathrm{~m}^{2}$ for open space in large neighborhoods with additional $1.2-0.70 \mathrm{~m}^{2}$ for out-door sport fields [31]. The proposed standards for accessibility are [31]:

- $\quad 300-200 \mathrm{~m}$ to the nearest cluster open space.

- $\quad 500-300 \mathrm{~m}$ to the nearest neighborhood open space.

- $\quad 500-300 \mathrm{~m}$ to the nearest sport field.

Khartoum Structure Plan [32] proposed increase in green areas by developing the river Nile front embankments in Khartoum, Khartoum North and Omdurman as public parks

Residential areas in Khartoum have three distinctive classes:

- $\quad$ First class -plot size is ranging from 800 to $500 \mathrm{~m}^{2}$ and inhabited by high income residents.

- Second class-plot size is ranging from 400 to $300 \mathrm{~m}^{2}$ and inhabited by medium income residents.

- Third class-plot size is $200 \mathrm{~m}^{2}$ and inhabited by low income residents.

\section{Selected Case Studies}

Sudan is located in North-Eastern Africa. Its area is roughly $1,765,048 \mathrm{Km}^{2}$. The population was estimated in 2018 as $41,511,526$ and $35.3 \%$ of the population is urban. The density is 24 persons per sq.km [33]. Khartoum city -the capital is located in the center of Sudan at the confluence of the White Nile and the Blue Nile. Khartoum city is also the capital for Khartoum State, one of 18 Sudanese states. Khartoum State area is $22.142,000 \mathrm{~km}^{2}$ and its population has grown to 7,687,547 [34].

The research selected six neighborhoods in Khartoum city as case-studies. They represent different residential classes (first, second and third) and different time of planning (old neighborhoods and new ones). They are also differing in size, some are large and others are small. The selected neighborhoods are:

- $\quad$ First class residential areas: Khartoum -2 (1950), and Al Mujahedeen (1988).

- $\quad$ First class + second class residential area Al Riyadh (1972).

- $\quad$ Second class residential area: Al-Amarat (1958)

- Third-class residential areas: Al Diyum (1953) and Nasr Extension (1972).

Location of these neighborhoods is shown in fig 1 below.

\section{Research Methodology}

The research has followed qualitative and quantitative methods which included: analysis of documents, photo documentation, observation, and statistical data. The statistical data -concerning area and population of each neighborhood- are collected from Governmental Reports [35].

The field survey was performed in July-December 2017. The research has three levels of analysis:

1- A comparison between the characteristics of the selected neighborhoods (geospatial data) to outline developed open spaces, index of sufficiency and the planning pattern of open spaces.

2- Classification of developed open spaces in the selected neighborhoods and evaluation of the performance of each typology.

3- Analysis of developed open spaces using the international indicators of development of open spaces. These indicators represent the most important aspects needed to develop open spaces [7] and [21]. The indicators are: Availability, Accessibility and Security.

The research added Management as a fourth indicator. Each indicator is expanded into components e.g.:

- Availability includes area of open space, the percentage of green coverage and the type of landscape whether green landscape or grey landscape.

- Accessibility includes distance to the nearest open space and percentage of street frontage of the open space.

- Security includes provision of lighting and fence.

- Management includes the developer of the open space and the manager. 


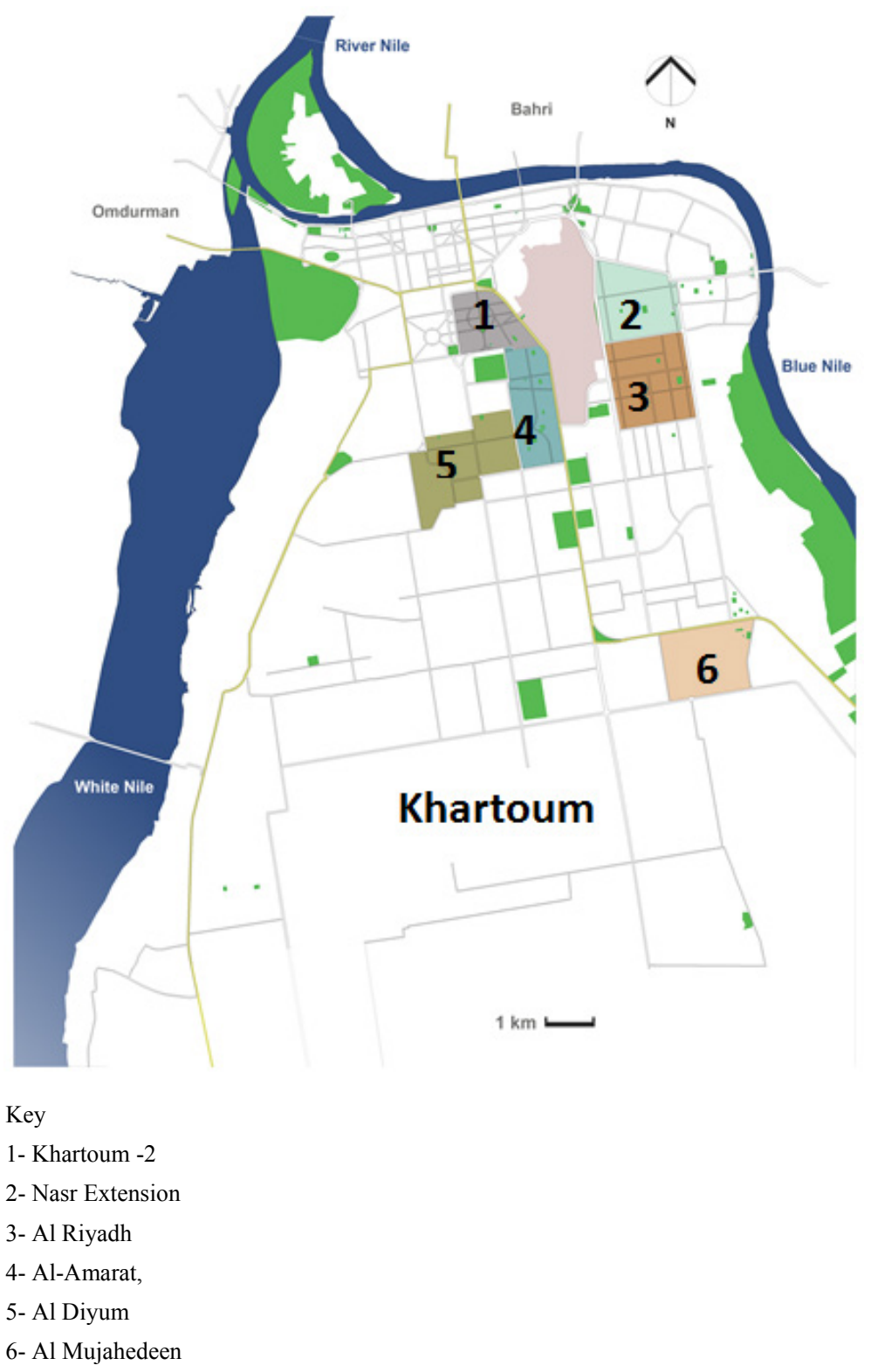

Figure 1. Location plan of the selected neighborhoods (Source: [32])

\section{Discussion}

\subsection{Comparison between the Selected Neighborhoods}

Generally speaking most neighborhoods have acceptable index of sufficiency e.g. Khartoum -2 (8.9) Al-Riyadh (8.7), Al-Diyum (7.7) and Naser Extension (5.7), compared to the international standards of $10 \mathrm{~m}^{2}-6 \mathrm{~m}^{2}$ (see table 3). More detailed observation revealed that residential class and time of planning are influential factors on index of sufficiency. Old neighborhoods have higher index value than new neighborhoods e.g. Khartoum (2) (8.9) compared to Al-Mujahdeen (5.2) and Al-Diyum (7.7) compared to Naser Extension (5.7) see table 3. Also first class residential areas have higher index value than third class areas e.g. Khartoum -2 (8.9) compared to Al-Diyum (7.7).

The developed open spaces are 35 with total area of
$154,050 \mathrm{~m}^{2}$ which represent only $27.6 \%$ of the total number of open spaces - 187 with total area of $558,699 \mathrm{~m}^{2}$, as shown in table 3. The percentage of developed open spaces is higher in first and second-class residential neighborhoods e. g. Khartoum $2(65 \%)$ and Al-Amarat $(57.6 \%)$ than third class residential neighborhoods e.g. Naser Extension (27\%) and Al-Diyum (21. 4\%). The inhabitants of these neighborhoods are affluent and can afford spending some money to develop their open spaces.

When comparing the index of sufficiency of open spaces with the index of sufficiency of developed open spaces, the actual index of sufficiency of developed open space reduced dramatically e.g. Khartoum -2 from 8.9 to 5.8 and Al-Diyum from 7.7 to 1.6 .

It indicates a severe shortage in provision of developed open spaces (see figure 2).

Regarding the distribution of open spaces in the selected 
neighborhoods, some open spaces have hierarchy according to the housing cluster. They range from semi-communal open spaces within plots of houses up to communal open spaces which serve larger group of houses. The hierarchy exists in old neighborhoods e.g. Al-Diyum, each plot of houses should have direct access to the semi-communal open space (see fig 3). While new neighborhoods have non-hierarchical open spaces e.g. Al-Mujahdeen (see fig 4). However, the hierarchy provision of open spaces is not appropriate to children's play and sports facilities.

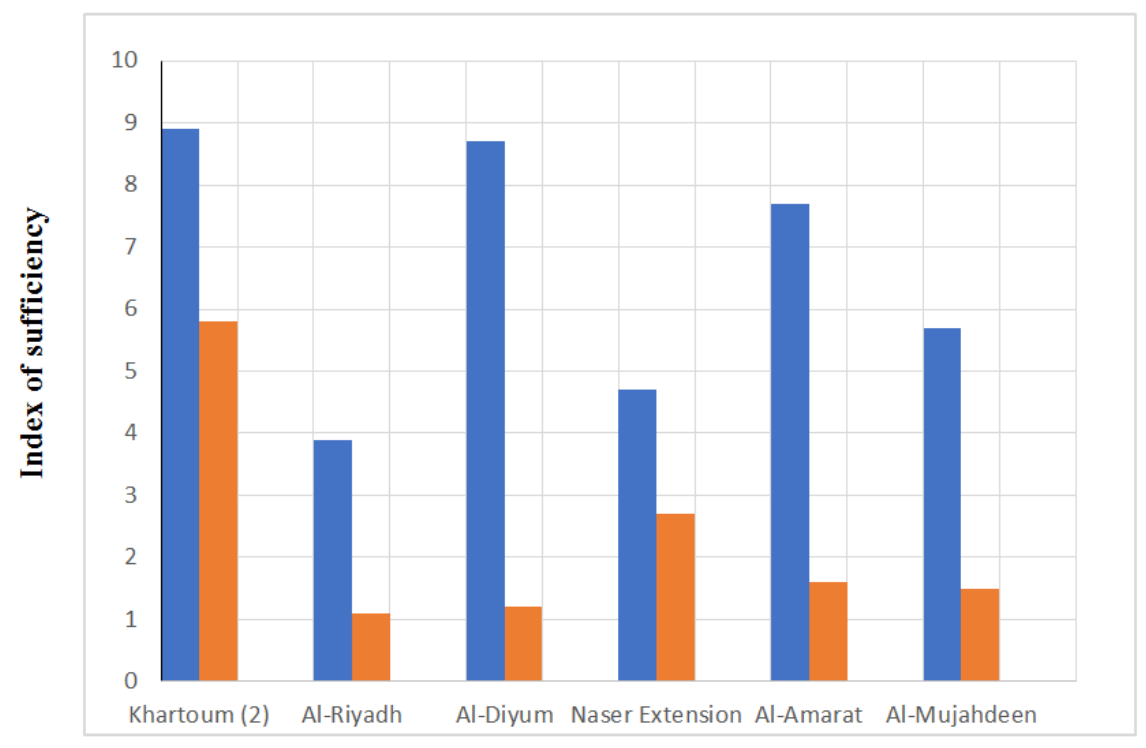

\section{Neighborhoods}

Key
$\square$
$\square$

index of sufficiency of open space

index of sufficiency of developed open space

Figure 2. The index of sufficiency of open spaces in the selected neighborhoods. Source: The researcher

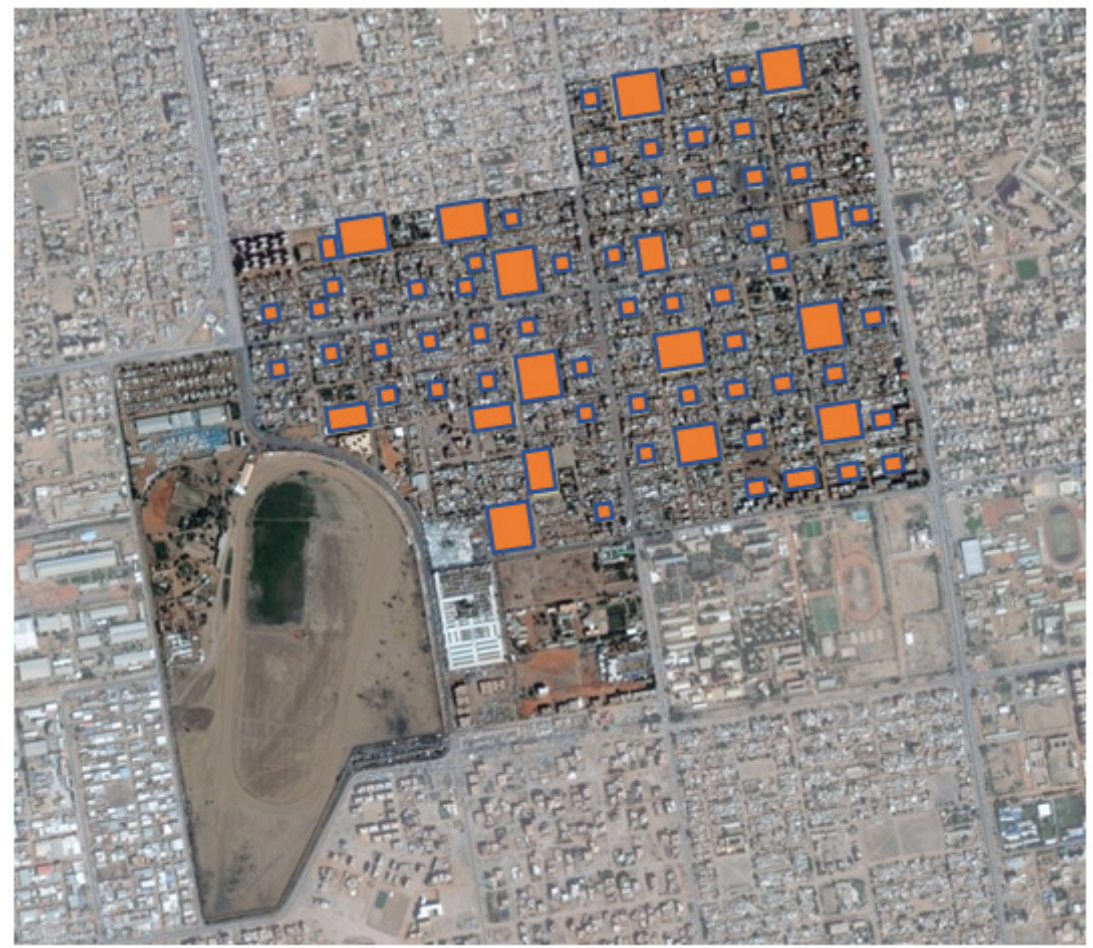

(Source: Google Map 2016)

Figure 3. hierarchy of open spaces in Al-Diyum Neighborhood 


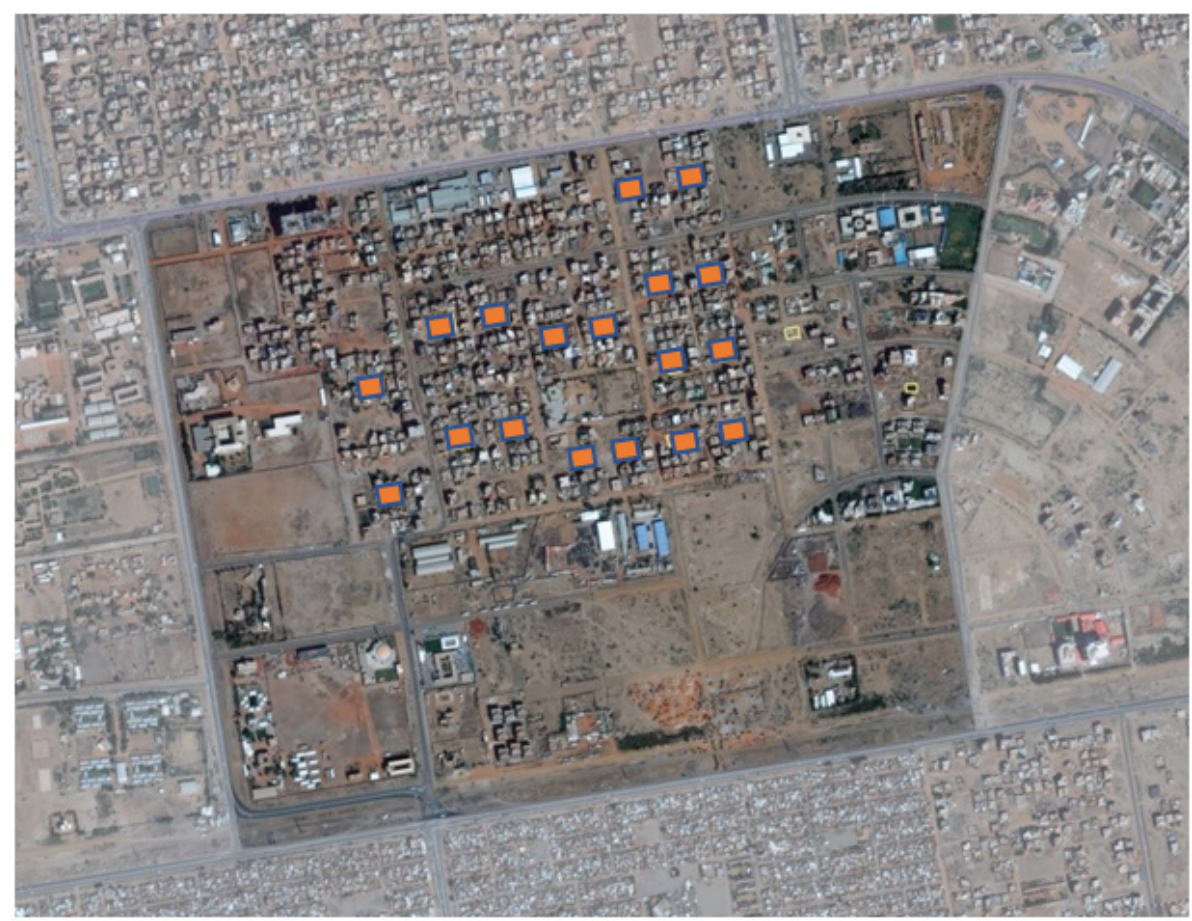

(Source: Google Map 2016)

Figure 4. non-hierarchical open spaces in Al-Mujahdeen Neighborhood

Table 3. Characteristics of developed open space in the selected neighborhoods.

\begin{tabular}{|c|c|c|c|c|c|c|c|c|}
\hline Neighbour-hood & $\begin{array}{l}\text { Residential } \\
\text { class }\end{array}$ & $\begin{array}{l}\text { Area } \\
\left(\mathrm{m}^{2}\right)\end{array}$ & $\begin{array}{l}\text { Inhabitants } \\
\text { (person) }\end{array}$ & $\begin{array}{l}\text { open } \\
\text { spaces }+ \\
\operatorname{area}\left(\mathrm{m}^{2}\right)\end{array}$ & $\begin{array}{l}\text { index of } \\
\text { sufficiency } \\
\text { of open } \\
\text { space }\end{array}$ & $\begin{array}{l}\text { Develop-ed } \\
\text { open } \\
\text { spaces }+ \\
\text { Area }\left(\mathbf{m}^{2}\right)\end{array}$ & $\begin{array}{l}\text { Develop-ed } \\
\text { open } \\
\text { spaces \% }\end{array}$ & $\begin{array}{l}\text { index of } \\
\text { sufficiency } \\
\text { of } \\
\text { developed } \\
\text { open } \\
\text { space }\end{array}$ \\
\hline Khartoum (2) & First & $1,457,870$ & 4,871 & $\begin{array}{l}13 \\
41,850\end{array}$ & 8.9 & $\begin{array}{l}6 \\
27,490\end{array}$ & 65.7 & 5.8 \\
\hline Al-Mujahdeen & First & 900,000 & 5552 & $\begin{array}{l}18 \\
28,800\end{array}$ & 5.2 & $\begin{array}{l}4 \\
6400\end{array}$ & 34.0 & 1,1 \\
\hline Al-Riyadh & $\begin{array}{l}\text { First }+ \\
\text { second }\end{array}$ & $2,774,538$ & 12,797 & $\begin{array}{l}31 \\
107,000\end{array}$ & 8.7 & $\begin{array}{l}3 \\
15,800\end{array}$ & 14.8 & 1.2 \\
\hline Al-Amarat & second & $2,050,160$ & 8,184 & $\begin{array}{l}31 \\
38,120\end{array}$ & 4.7 & $\begin{array}{l}8 \\
21960\end{array}$ & 57.6 & 2,7 \\
\hline Al-Diyum & third & $2,562,896$ & 29,616 & $\begin{array}{l}65 \\
226,609\end{array}$ & 7.7 & $\begin{array}{l}8 \\
48400\end{array}$ & 21.4 & 1.6 \\
\hline Naser Extension & third & $2,214,515$ & 22205 & $\begin{array}{l}35 \\
126,320\end{array}$ & 5.7 & $\begin{array}{l}6 \\
34000\end{array}$ & 27.0 & 1.5 \\
\hline
\end{tabular}

Source: The field survey- July-December 2017

\subsection{Developed Open Space Typology}

User-perception surveys revealed that developed open spaces within the selected neighborhoods differ in functions. Each community has variety of activities that can be performed in open spaces, but the most prevailing activities and occasions occur in outdoor spaces are: children playing, sports, social adults gathering, eating in
Ramadan and even wedding parties and mourning the dead. However, developed open spaces in the selected neighborhoods can be classified upon their use into six groups: Promenading open space, Gated open space, Recreational Open space, Community centers, Sport fields and Cluster open space. Table 4 presented detailed description of each typology. 
Table 4. Developed open space typologies in the selected neighbourhoods.

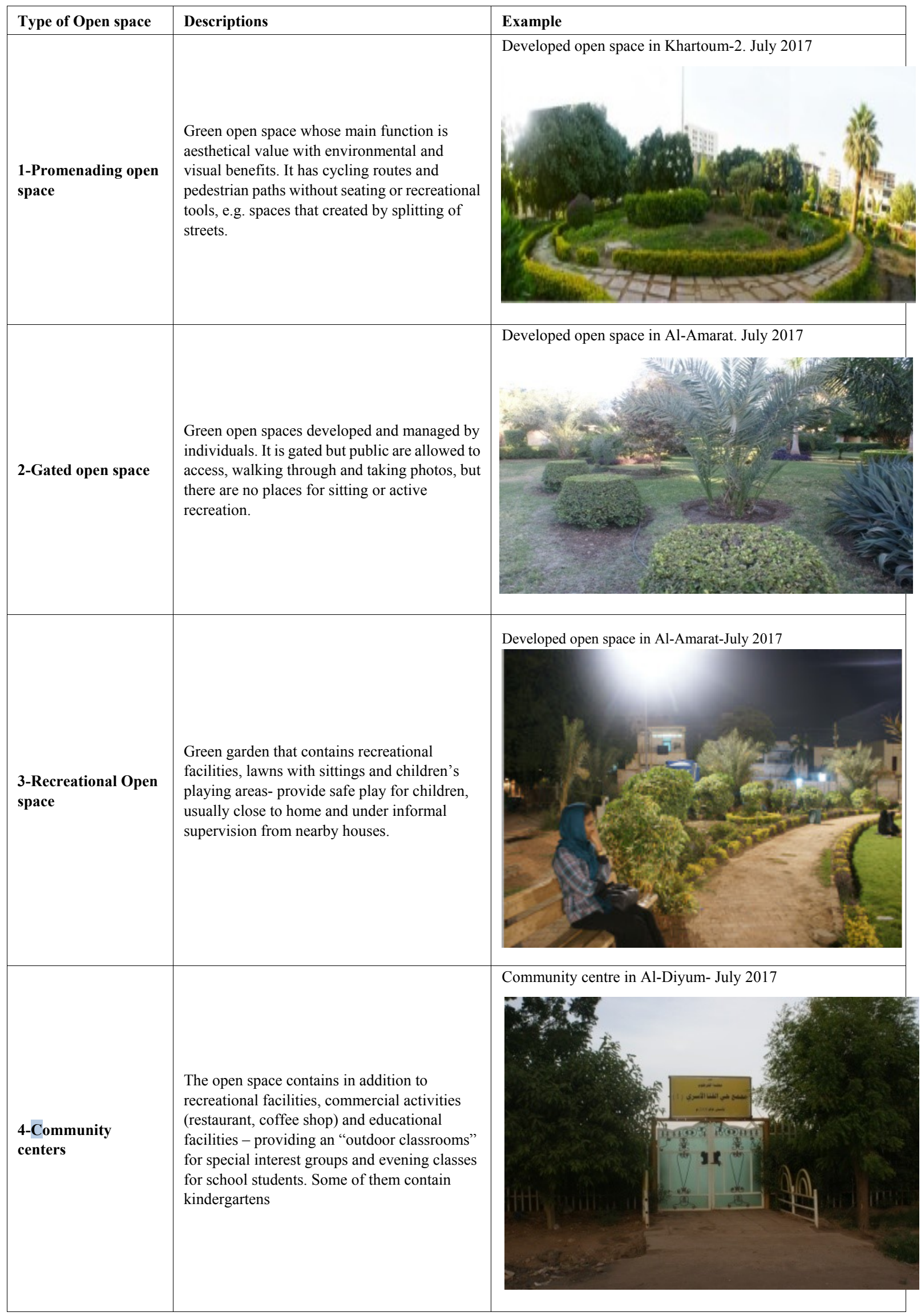




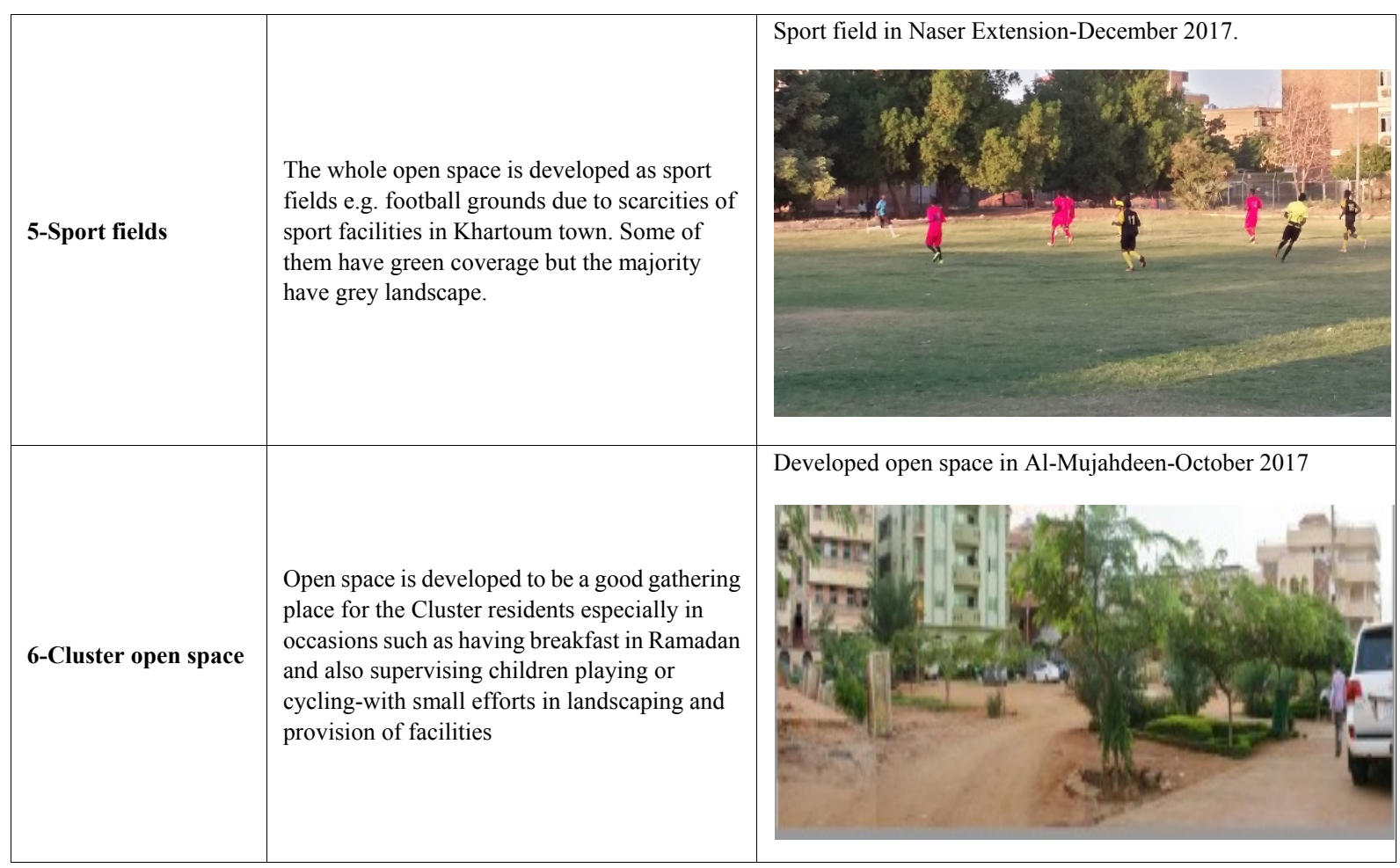

Source: The field survey July-December 2017

The research grouped the broad and diverse benefits of open spaces in neighborhoods presented in the introduction section, into four main impacts: Environmental/Ecological Impact, Life style Impact, Social Impact and Equity Impact. They are the most effective impacts of open spaces. Then formulated a model to evaluate the performance of the six typologies of open spaces found in the selected neighborhoods are as follows:

- Environmental/Ecological Impact and related suggested factors are: improve air quality and reduce risk of flooding, support water management, support contact with nature and enhance biodiversity.

- Life style Impact and related suggested factors are: increase physical activity level, enable active transport by foot or bike, Increase the time people spend out-door and support healthy lifestyle and active recreation.

- Social Impact and related suggested factors are: support social cohesion and promote social interaction.

- Equity Impact and related suggested factors are: encourage all groups to use open space and enable different functions. 
Table 5. Evaluation of developed open spaces performance.

\begin{tabular}{|c|c|c|c|c|c|c|c|}
\hline \multicolumn{2}{|r|}{ Impacts } & Promenading & Gated & Recreational & Community & Sport field & Cluster \\
\hline \multirow{4}{*}{$\begin{array}{c}\text { Environmental } \\
\text { /Ecological }\end{array}$} & Improve air quality and reduce risk of flooding. & strong & strong & strong & strong & weak & weak \\
\hline & Support water management & strong & strong & strong & strong & moderate & strong \\
\hline & Support contact with nature & strong & strong & strong & strong & weak & weak \\
\hline & Enhance biodiversity & strong & strong & strong & strong & weak & weak \\
\hline \multirow{4}{*}{ Life style } & Increase physical activity level & strong & strong & strong & strong & strong & moderate \\
\hline & Enable active transport by foot or bike & strong & strong & strong & strong & strong & moderate \\
\hline & Increase the time people spend out-door & strong & strong & strong & strong & strong & strong \\
\hline & Support healthy lifestyle and active recreation & strong & strong & strong & strong & strong & strong \\
\hline \multirow{2}{*}{ Social } & Support social cohesion & moderate & moderate & strong & strong & moderate & strong \\
\hline & Promote social interaction & moderate & moderate & strong & strong & moderate & strong \\
\hline \multirow{2}{*}{ Equity } & encourage all groups to use open space & moderate & moderate & strong & strong & weak & strong \\
\hline & Enable different functions & weak & weak & strong & strong & weak & strong \\
\hline
\end{tabular}

Source: The researcher 
Application of the proposed model on the typologies of developed open spaces is presented in table 5. The evaluation is based on strong, moderate or weak impact of each factor. The result revealed that Recreational type and Community type have strong impacts in all the factors, as they are well developed to serve all the neighborhood residents. The Promenading type and Gated type have strong impact in environmental/ecological and lifestyle factors and moderate impact in social factors and weak impact in equity factors because they do not enable different functions. The Sport field type has weak impact in environmental/ecological factors because most of sport fields have grey landscape. It has weak impact in equity factors because it is used by youth and children only and does not enable different functions. The Cluster type has strong impact in social and equity factors, moderate impacts in lifestyle factors and weak impacts in environmental/ecological factor because most of Cluster open spaces are not well developed with green landscape.

\subsection{Development Indicators of Open Spaces in Neighborhoods.}

\subsubsection{Availability}

The geospatial analysis of the selected neighborhoods revealed that developed open spaces take several shapes and sizes. Each neighborhood has different sizes of open spaces except Al-Mujahdeen neighborhood. As the newest neighborhood, Al-Mujahdeen has open spaces of the same size- $1600 \mathrm{~m}^{2}$. Sizes of developed open spaces range from $1200 \mathrm{~m}^{2}$ to $12500 \mathrm{~m}^{2}$. Small open spaces $\left(1200 \mathrm{~m}^{2}-3000\right.$ $\mathrm{m}^{2)}$ represents $60 \%$ of the total open spaces. Medium open spaces $\left(3200 \mathrm{~m}^{2}-6000 \mathrm{~m}^{2}\right)$ represent $14.3 \%$ of the total open spaces. Large open spaces $\left(6200 \mathrm{~m}^{2}-12500 \mathrm{~m}^{2}\right)$ represent $25.7 \%$ of the total open spaces. The size of open space can vary considerably with the actual design of houses and the inner gardens; so that, it is much less important in first class residential areas where houses have large gardens than in third class residential areas where houses are small with less possibilities of gardens. $65.7 \%$ of developed open spaces have green land scape with green coverage more than $50 \%$ of the total area as shown in table 5 .

\subsubsection{Accessibility}

The accessibility of developed open spaces is related to the number of these spaces and their distribution within neighborhoods. Developed open spaces are obviously randomly distributed within the neighborhoods so that only 15 developed open spaces- which represent $42.8 \%$ - have good accessibility ranging from $122 \mathrm{~m}-300 \mathrm{~m}$ compared to the international standard of $300 \mathrm{~m}$. They are located in first and second-class residential areas e.g. Khartoum (2), Al-Amarat and Al-Mujahdeen. The remaining 20 open spaces have bad accessibility ranging from $344 \mathrm{~m}-1075 \mathrm{~m}$, they are located in - third class residential areas e.g. Al-Diyum and Naser Extension. Almost all developed open spaces are surrounded by streets at all direction except four open spaces.

\subsubsection{Safety}

Most of developed open spaces- $85.8 \%$ - have lighting which to some extent guarantee the safety of women, elderly and children walking by or using these areas. $74.3 \%$ of the developed open spaces are fenced. That indicates a growing tendency of green space being locked behind walls and prevents the public from using them. Thus, enhances the social inclusion dimension. Developed open spaces that have lighting and a fence represent $68.5 \%$ of the total developed open spaces, while only two developed open spaces have no lighting or a fence.

\subsubsection{Management}

Generally, neighborhood open spaces in Khartoum town are owned by local government authority, in some cases they are privately owned. The privately-owned open spaces are usually developed and managed privately by landowners. In the selected neighborhoods, most developed open spaces are managed by public participation $-65 \%$ of them by community groups and $12 \%$ of them by individuals (see figure 5) at their own expense, and sometimes have assistance from the town local authorities. Some open spaces have commercial activities such as cafes to meet user needs and to add to attractiveness to the open space and thus the neighborhood.

The field survey revealed that factors ontribute to well management of open spaces are:

- A well organized and active community participation.

- A local person who acts as a leader of the local community who can gain legal support.

- Clear security for the space, usually in the form of fencing and lighting.

- Use of the space by different age groups of the community.
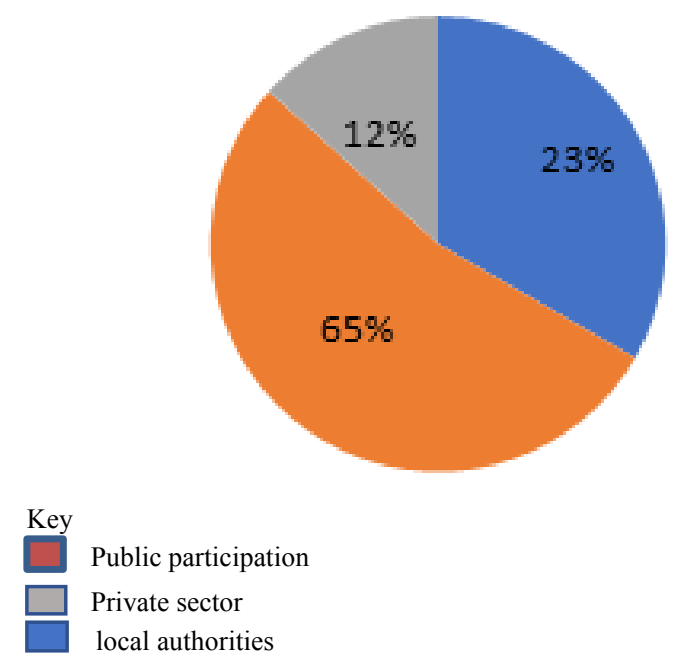

Source: Field survey July-December 2017

Figure 5. Management of developed open spaces in the selected neighborhoods. 
Table 6. Development Indicators of open spaces

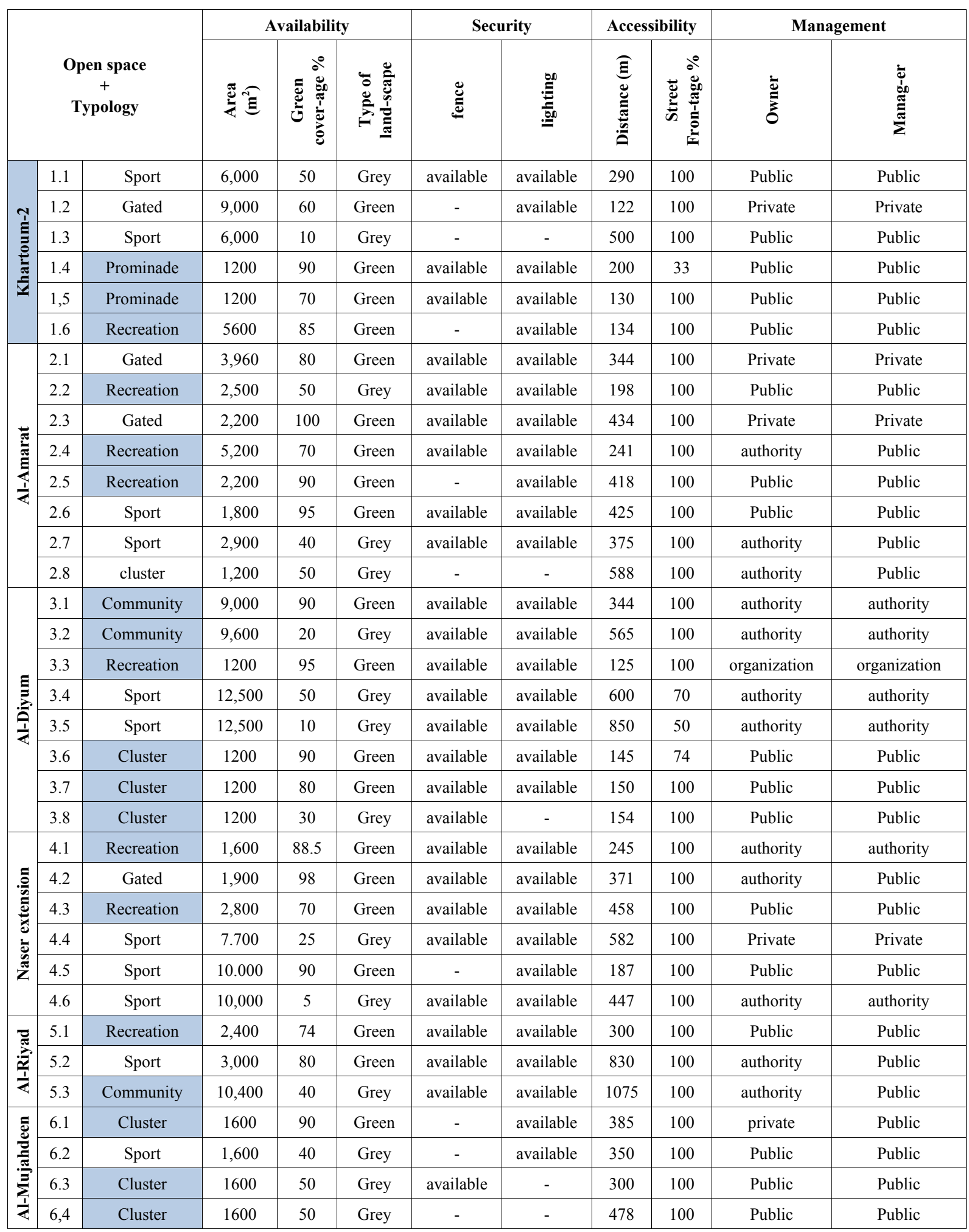

Source: field survey July-December 2017 


\section{Conclusions}

The absence of a comprehensive development program for open spaces in the selected neighborhoods leads to poor outdoor environments. Well designed and well managed open spaces can be used for play, recreation, and relaxation, they can also encourage neighborhood's residents to involve in out-door activities which enhance social interaction and sense of community.

The research added a quantitative perspective on previous researchers' more qualitative studies on open spaces within neighborhoods. The developed open spaces in the selected neighborhoods are 35 with total area of $154,050 \mathrm{~m} 2$ which represent only $27.6 \%$ of the total number of open spaces. The comparison between the selected neighborhoods revealed that old neighborhoods have hierarchical open spaces while new neighborhoods have non-hierarchal open spaces.

The field survey also disclosed a strong influence of a set of factors such as residential class and time of planning on the development of open spaces in each neighborhood. The comparison between high income - first class neighborhoods e.g. Khartoum $2(65 \%)$ and low income -third class neighborhoods (e.g. Al Diyum (21.4\%)) revealed that first class neighborhoods have more developed open space than third class areas,

The research classified developed open spaces in the selected neighborhoods upon their use into six groups: Promenading open space, Gated open space, Recreational Open space, community centers, Sport fields and Cluster open space. Also, the research formulated a model to evaluate the performance of the six typologies of open spaces in the selected neighborhoods based on environmental/ecological, lifestyle, social and equity impacts. The successful examples of developed open spaces of the surveyed neighborhoods are Recreational open spaces and Community centers.

The research promoted a set of indicators to evaluate development of open spaces in neighborhoods such as: availability, accessibility, security and management and it was clear that small open spaces $(1200 \mathrm{~m} 2-3000 \mathrm{~m} 2)$ represents $60 \%$ of the total open spaces. $65.7 \%$ of developed open spaces have green land scape with green coverage more than $50 \%$ of the total area. Accessibility of developed open spaces in first and second-class neighborhoods is better than third class neighborhoods. $68.5 \%$ of the total developed open spaces, while only two developed open spaces have no lighting or a fence .Developed open space of the surveyed neighborhoods managed by community groups (public participation) are estimated to be greater than that which is managed by the local authority and most of them have lighting and fences.

\section{REFERENCES}

[1] Regional Public Health: Healthy Open Spaces: A summary of the impact of open spaces on health and wellbeing, Regional Public Health Information Paper March 2010

[2] Kozloff,H. Understanding the Value of Urban Open Space. Urban Land Institute.2015.

[3] Thompson, C.W. Urban open space in the $21^{\text {st }}$ century. Landscape and urban Planning. Volume 60. Pp 59-72. 2002.

[4] Rapoport A. The role of neighborhood in the success of cities Ekistics, 69(412-414); pp 145-151. 2002.

[5] Swanwick C. Society's attitudes to and preferences for land and landscape. Land Use Policy. Volume 26, Supplement 1, Pages S62-S75. 2009.

[6] Kazmierezak,A.E and James,P. The role of urban green spaces in improving social inclusion. pp354-365. 2007.

[7] World Health Organization. Health Indicators of Sustainable Cities- Initial findings from a WHO Expert Consultation: 17-18 May 2012.

[8] Jennings, V, Larson,L, and Yun,J. Advancing Sustainability through Urban Green Space: Cultural Ecosystem Services, Equity, and Social Determinants of Health. International Journal of Environmental Research and Public Health. 2016

[9] Bell S, Hamilton V, Montarzino A, Rothnie H, Travlou Pand Alves S. Green space Scotland: research report. 2008

[10] Tsai W.1., McHale M.R., Jennings V, Marquet O., Aaron Hipp J. Leung Y.F. and Floyd M.F.Relationships between Characteristics of Urban Green Land Cover and Mental Health in U.S. Metropolitan Areas. International journal of environmental research and public health. 2018.

[11] Rakhshamdehroo M and Johari M. The environmental benefits of urban green spaces. Alam Cpita. Volume 10 (1). pp10-16.2017.

[12] Campbell, K. Rethinking Open Space, Open space Provision and Management: A Way Forward, Report presented by Scottish Executive Central Research Unit, Edinburgh, Scotland, UK. 200

[13] Mensah,C.A.and Roji A. Urban green spaces in Africa. Insights from selected African cities. Landscape Ecology.No.62 2014

[14] Baycan T. Nijkamp,P .Critical success factors in planning and management of urban green spaces in Europe. International Journal of Sustainable Society. 2007.

[15] Shirley, P. The Urban Park, In M. Cliff (ed.), Urban Design: Green Dimensions, Elsevier, Architectural Press, Oxford, UK, pp. 77-92. 2005

[16] Urban Green Spaces Task Force. Green Spaces, Better Places-Final report of the Urban Green Spaces Task Force. DTLR, London. 2002.

[17] Green Surge Project. A typology of urban green spaces,ecosystem services provisioning services and demands.Vol.10. 2015. 
[18] UN Habitat, Habitat III issue papers 11 - Public Space, New York.2015.

[19] United Nations. (n.d.). Sustainable Development Goals SDGs. Retrieved October 2016, from Sustainable Development: www.sustainabledevelopment.un.org.

[20] UNDP. Melbourne Principles for Sustainable Cities. United Nations Environment Programme Division of Technology, Industry and Economics. 2002.

[21] Al-Hagja K. Towards a sustainable neighborhood's role of open spaces. International journal of architectural research. volume 2-Issue 2- pp162-177. July 2008.

[22] You,N. Toward a global action plan for public space-Bridging the urban SDG with Habitat III. Citiscope. 2015

[23] WHO Regional Office for Europe. Urban green space a brief for action. Copenhagen: WHO Regional Office for Europe. 2017.

[24] Mahon.J.R and.Miller R.W.Identifing high-value green space prior to land development .J.Architecture.20 (1) .pp 25-33. 2003

[25] Herbits $\mathrm{H}$ and Herbits V. The development of an evaluation method using a geographic information system to determine the importance of wasteland sites in urban wildlife are as landscape urban plan .77. pp 176-195. 2006.

[26] Randall T. A, Churchill C.J. and Baetz B.W. 2003.A GISbased decision support system for neighborhood greening. Environ Plan-SAGE journals.30 (4). pp541-563.

[27] Comber A, Brunsdon C, Green E.1 Using a GIS-based network analysis to determine urban greenspace accessibility for different ethnic and religious groups. Landscape and Urban Planning. Volume 86, pp 103-114. 2008.

[28] UN Habitat, Enhancing Urban Safety and Security .Global Report on Human Settlements . 2007.

[29] Alhuseen,. "Sufficiency of Open Public and Green Spaces in Khartoum State-Sudan", International Journal of Social Relevance \& Concern (IJSRC) ISSN-2347-9698, Volume 3, Issue 5. 2015.

[30] Ministry of physical planning. Sudan Report for Habitat II, 1996.

[31] Committee for physical planning. The Planning Directory for Social Services. Khartoum State. 2016.

[32] Khartoum State: Ministry of planning and physical planning. Khartoum Structure Plan. Volume 1. Khartoum State. 2009.

[33] http://www.worldometers.info/world-population/sudan-pop ulation/ accessed 14/11/2018

[34] https://wikivisually.com/wiki/Khartoum_\%28state\%29\#Ref erences. accessed 14/11/2018.

[35] Khartoum State. Governmental Reports-Khartoum . Khartoum State.2015. 